\title{
Professor Jerzy Bowszyc, Honorary Editor-in-Chief of Postępy Dermatologii i Alergologii/Advances in Dermatology and Allergology, is dead
}

\author{
Wojciech Silny
}

Postep Derm Alergol 2014; XXXI, 3: 125-126 DOI: 10.5114/pdia.2014.43188

It is with deep regret and profound sadness that we announce the passing away of the Honorary Editor-in-Chief of Postępy Dermatologii i Alergologii/Advances in Dermatology and Allergology, great humanist, outstanding scholar and clinician respected by Polish and foreign dermatologists - professor Jerzy Bowszyc on 10 March 2014.

Professor Bowszyc was born on 25 March 1932 in Vilnius in a family of teachers. He was raised in a religious and patriotic household. In 1945, together with his parents, he repatriated to Poland. In 1955, he obtained a medical diploma from the Medical

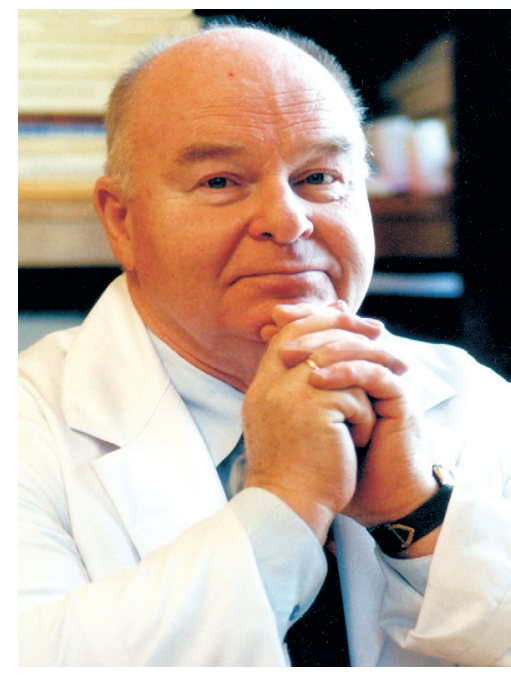

His scientific and clinical activity can be divided to two periods. In the first period professor Bowszyc was related with the Department of Skin and Venereal Diseases in Gdansk, where under the guidance of a wellknown scientist and clinician - professor Franciszek Miedziński - he learnt and thoroughly studied the arcana of dermatology and venereology and got to know his research techniques. Further intensive research work and improvement of his techniques resulted in a lot of research papers on immunopathology of skin diseases. Year 1977 marked the end of the first period of Professor's research and clinical career University in Gdansk. In 1962, he became a specialist in dermatology and venereology, in 1962 he defended his doctoral dissertation, and then in 1976 he received a postdoctoral degree. In 1983, he was appointed extraordinary professor and in 1989, he became a full professor.

In his scientific interests and work the Professor focused mainly on sexually transmitted diseases, eczema, immunopathology as well as cryotherapy and Roentgen therapy. The Professor was involved in epidemiology, pathomechanism and diagnosis of syphilis. He took note of a great role of the cellular and humoral response in the pathomechanism of that disease and presented various treatment methods and assessed their efficacy during long-term observations. These papers were very popular among readers. The Professor was also interested in allergic diseases of the skin, for example contact dermatitis, urticaria and drug eruptions. He devoted a series of papers to penicillin, allergic and non-allergic reactions after penicillin administrationand methods of in vitro diagnosing hypersensitivity to drugs. Professor Bowszyc's publications covered a variety of topics starting from clinical experiment works to highly valued handbooks, monographs, textbooks, review articles, reviews and translations. and also the beginning of the subsequent one. On 1 October 1977, professor Bowszyc became the head of the Department and Clinic of Dermatology in Poznan, which he managed until 2002. That was a period of the most dynamic development of the Poznan Clinic in research, educational, service-providing and organisational terms in its post-war history. Under Professor's supervision, the Clinic expanded its laboratory and diagnostic facilities, acquired new - at times unique - diagnostic apparatus and intensified its research work. A number of research groups and laboratories were formed, such as Blistering and Connective Tissue Disease Laboratory, Cosmetic Assessment Laboratory, Cryotherapy and Cryobiology Laboratory, AIDS Laboratory, Allergic Disease Diagnostic Laboratory and Mycology and Bacteriology Laboratory. On professor Bowszyc's initiative, individual research groups established relationships with a number of research centres in Poland and abroad, which resulted in exchange of experience, staff training and joint publications. Co-operation with the industry, in particular pharmaceutical and cosmetic industry, was also developed. Thanks to this, the scope of service-providing and educational activities was broadened. Professor Bowszyc started to restructure the service-providing activities of the Clinic by changing the 
service provision from in-patient to out-patient basis. The number of beds at the Clinic was reduced and wards were renovated and adapted to meet applicable requirements. Furthermore, modern medical equipment was purchased for a number of diagnostic laboratories of the Clinic.

Supervised by professor Bowszyc, in 1977-2002, Poznan Clinic staff published about 600 research manuscripts - including a few dozen manuscripts in foreign journals, delivered over 300 papers or reports at Polish and foreign meetings, congresses and symposiums, issued 30 monographs or chapters in handbooks, textbooks or atlases.

Scientific achievements of professor Bowszyc are impressive. He authored or co-authored over 350 original and review publications, 15 textbooks, monographs or chapters and delivered numerous speeches at conferences and symposiums in Poland and abroad. His clinical works about sexually transmitted diseases as well as cryotherapy and Roentgen therapy are a huge success. The Professor habilitated 6 people, supervised 18 doctoral theses and was a reviewer of a lot of postdoctoral and doctoral papers and scientific achievements of candidates for professors. Under his supervision, a few dozen doctors got specialities in dermatology and venereology.

Professor Bowszyc was a highly valued dermatologist in and outside Poland. He was often invited as a lecturer to European centres, actively participated in numerous national and foreign meetings. He was also active in the work of the Main Board of the Polish Dermatological Society, he was its President and a member of the Presidium for many terms of office.
One of his most important achievements was the journal Advances in Dermatology he launched and created. The journal was first published in 1984 with professor Bowszyc as its Editor-in-Chief. In 2001, professor Wojciech Silny became the Co-Editor-in-Chief, Advances in Dermatology was transformed into a quarterly and then a bimonthly, the journal layout was changed and now the journal is published as Postępy Dermatologii $i$ Alergologii/Advances in Dermatology and Allergology. Professor Bowszyc was the Honorary Editor-in-Chief from 2005 until his death.

Scientific, clinical and educational activity of professor Bowszyc was recognised and appreciated by Polish and world dermatological circles.

Professor Bowszyc was an honorary member of the German and Czech Dermatological Societies. He was also awarded a number of scientific awards, the Gold Cross of Merit and Order of Polonia Restituta.

We all knew professor Bowszyc as a person who is direct, approachable and open, who can laugh and joke and is always ready to bring help to everybody expecting it. A Great Man passed away, a person of integrity and kindness. Professor Bowszyc was buried at the Miłostowo cemetery in Poznanand his funeral was attended by the family, friends, colleagues, authorities of the Poznan University of Medical Sciences and the Polish Dermatological Society.

Dear Professor,

Your work will be continued and you will live in our memories and hearts forever.

\footnotetext{
Professor Wojciech Silny

Editor-in-Chief of Postępy Dermatologii i Alergologii/Advances in Dermatology and Allergology Head of the Chair and Clinic of Dermatology of the Poznan University of Medical Sciences in 2002-2012
} 